Original research article

\title{
Research into the needs of families who have children with Down syndrome (in the Slovak framework)
}

\author{
Miriam Slaná *, Katarína Molnárová Letovancová, Patricia Dobríková, Michaela Hromková \\ Trnava University in Trnava, Faculty of Health Sciences and Social Work, Department of Social Work, Trnava, Slovak Republic
}

\begin{abstract}
Objective: The objective of the research was to identify the current needs of parents who have children with Down syndrome (DS); needs which were not satisfied at the time when DS was diagnosed in the child, and to describe the nature of the relationship between the needs of parents who have children with DS and their quality of life.

Methods: Two valid standardized scales were applied in the research: the Family Needs Survey (FNS) and the Family Quality of Life Scale (FQOL). The research sample consisted of 102 parents of children with DS. The obtained data were processed using content analysis of data and statistical data processing through SPSS.

Results: The research shows that it was right after the birth of their DS child that parents felt they most lacked information and psychological assistance. As their children grew older, they needed more formal or informal support, financial assistance, engagement of their DS child in the educational process, and they also felt a shortage of time. At the same time, a strong factor with a positive impact on the needs of parents of DS children $(U=448 ; p<0.05)$ and their quality of life $(U=146 ; p<0.05)$ was the support of grandparents and self-help communities $(\alpha=52.78 ; p<0.05)$. The higher the quality of the parents life, the lower the needs in terms of family functioning $\left(r_{s}=-0.267 ; p>0.01\right)$, use of community services $\left(r_{s}=-0.278 ; p>0.01\right)$ or the necessity to acquaint the community with the child's disability $\left(r_{s}=-0.280 ; p>0.01\right)$.

Conclusions: In order to satisfy the needs of families with DS children, formal and informal support is equally important. The types of support vary throughout the children's lives. Services provided to these families should not only be complex, but also coordinated and continuous.
\end{abstract}

Keywords: Down syndrome; Needs; Parents and disability; Quality of life

\section{Introduction}

Any health problem of a child requires increased care, time, money and energy from the parents. Parenting a child with Down syndrome is a particular challenge, as the extra chromosome causes imperfections in various areas of the child's physical and mental development. The risk of specific problems also increases, and parents need to prevent them from occurring (Šustrová et al., 2004).

Down syndrome is a chronic condition caused by a chromosomal anomaly that occurs on average in one out of 700 to 800 live-born children (Nunes and Dupas, 2011) and affects individual development in childhood and adulthood (Alexander and Walendzik, 2016). Experts, whose experience and knowledge inspired our research (Selikowitz, 2011; Šustrová et al., 2004) report that there are more than a hundred differences in children with Down syndrome, but $95 \%$ of children affected by Down syndrome have standard trisomy 21 (Alexander and Walendzik, 2016).
There are a number of specific health problems associated with Down syndrome. The most common are congenital heart disease, respiratory, visual and hearing problems, hypothyroidism, gastrointestinal diseases and growth disorders (Roizen et al., 2014). These require extra care and special attention and may be an additional source of concern and fear for parents (Alexander and Walendzik, 2016). Mental disability of children with Down syndrome (Pugnerová and Konečný, 2012) affecting their development, personality and socialization is a special symptom - and it is also the hardest to cope with. In children with Down syndrome, we observe cognitive and social deficits. Typical are severe learning disabilities (Feeley and Jones, 2008; Næss et al., 2011), attention deficit disorders (Ekstein et al., 2011), communication problems (Kumin, 2003), high frequency of compulsive repetitive behaviour (Evans and Gray, 2000), more pronounced incapability to comply with regulations and standards, difficulties in daily living activities such as hygiene, frequent conversations with oneself and social withdrawal (Feeley and Jones, 2008; Glenn and Cunningham, 2000).

\footnotetext{
* Author for correspondence: Miriam Slaná, Trnava University, Faculty of Health Sciences and Social Work, Department of Social Work, Univerzitné námestie 1, 91843 Trnava, Slovakia; e-mail: miriam.slana@truni.sk http://doi.org/10.32725/kont.2020.005

Submitted: 2019-06-27 • Accepted: 2020-01-20 • Prepublished online: 2020-02-20 
It is the individual emotional experience that is influenced by the diagnosis that brings many obstacles and limitations to the family of a child with Down syndrome. Families must spend a great deal of energy and patience in coping with the child's behavioural, emotional and health problems. They must also address the social consequences of the disease - as there is a potential threat of stigmatization (Alexander and Walendzik, 2016). After the birth of a child with Down syndrome, parents face a number of new facts that force them to change their way of life and thinking. Matějček (2001) even talks about it as a traumatic event. Parents may therefore face significant emotional problems, feelings of guilt, anger, sadness and frustration about the helplessness they experience due to the inevitability of the consequences of this disability, as well as depression, anxiety and somatic stress disorder. (Gallagher et al., 2008; Norizan and Shamsuddin, 2010). The psyche of the child's parents is not only affected by the diagnosis-related health problems, but also by practical problems related to caringfor a child with Down syndrome - such as financial problems, lack of information, lack of support (Gromošová, 2017; Vágnerová et al., 2009) troubles engaging in the education system (Gilmore et al., 2003) and the like.

In order to meet the health, physical and social needs of children with Down syndrome it is necessary to mobilize parents' resources, the welfare system and health care. During the early years of the child's development, early care is essential to minimize the impact of the disability and to compensate for deficits, especially in the family and institutions where the child spends time - the decisive factor in this process is to stimulate a child through a pleasant environment that is rich in educational activities (Duchoslavová, 2007; Šustrová et al., 2004). The adaptation of parents to the situation affecting the way the family system functions is very much dependent on the use of coping strategies (Spangenberg and Theron, 2001), the approach of medical staff (Slaná et al., 2017), the use of available resources (Haveman, 2007) and features of the family (Hauser-Cram et al., 2001; Sarimski, 2015).

Based on this expertise, we have set the objective of our research: to find out what needs the parents of a child who has Down syndrome currently have, and which needs were not met at the time of the diagnosis of Down syndrome.

\section{Materials and methods}

In our research, we applied two valid standardized global scales: the Family Needs Survey (FNS) and the Family Quality of Life Scale (FQOL).

The authors of The Family Needs Survey (FNS) are Bailey and Simeonsson (1988). It consists of 22 items focusing on the need for assistance in six areas - A Child (4 items), B Support (5 items), C Explaining to others (3 items), D Community Services (3 items), E Financial Needs (4 items) and F Family functioning (3 items). In each of these areas, the respondents should state to what extent they need help, ranging from: I definitely do not need help in this area, to I am not sure I definitely need help in this area. The questionnaire also includes an open question - What is most needed in your family right now? The minimum gross score is 22 , the maximum is 66 , and the higher the score the more help respondents need in each area.

The Family Quality of Life (FQOL) questionnaire was designed by Hoffman et al. (2006). It consists of 20 statements concerning respondent's satisfaction with areas such as spending time together, leading children to independence, support needed to relieve stress, support from friends, mutual assis- tance of family members with homework and other activities, family members' mobility, openness in communication, acquisition of social skills, space for interests, joint problem solving, support in achieving goals, external assistance and support, health care, safety, and the relationship with intervention providers for the child with the disability. Respondents are asked to express their satisfaction at 5 levels, from very dissatisfied to very satisfied. The gross score range is 20-100. As the score increases, respondents' satisfaction with their quality of life rises.

Standardized scales were supplemented with a self-designed socio-demographic questionnaire aimed at finding out information about the age, gender, marital status, highest level of qualification, employment and residence of parents of a child with Down syndrome. We also collected data about the child's age, gender and birth order from parents. In addition to the basic questions about demography, the questionnaire included questions on the relations between parents and grandparents of the child - in terms of their mutual assistance and co-existence. We were also interested in whether the child attends kindergarten or primary school. The last question aimed at finding out what kind of assistance was missing at the time the parents learned that their child had Down syndrome.

Data were collected throughout the year 2017. All data were processed by SPSS statistical program. The reliability of the Family Needs Questionnaire and the FQOL Questionnaire was high enough to reach FQOL $\alpha=0.945$, and the Family Needs Questionnaire reached $\alpha=0.898$ in our sample.

The normality of distribution was tested using the Kolmogorov-Smirnov test, the Mann-Whitney $U$ test, the KruskalWalis test, the Spearman's rank correlation coefficient, and the chi-square good fit test. The open question formulated in the questionnaire was evaluated through content analysis of data.

We used deliberate sampling to select the research sample. The sample in our research consisted of 102 parents of children with Down syndrome from Bratislava, Trnava, Košice and Žilina regions. We approached all of the parents of children with Down syndrome who were registered in organizations that focus on helping these families, and $68 \%$ out of 150 parents of children with Down syndrome who were registered in early intervention centres, outpatient clinics for children with Down syndrome, Up-Down association and Down Society in Slovakia agreed to participate in our research.

The respondents' age varied from 23 to 73, with the average age being 40 years, $M=40, S D=7.83$. Women accounted for $84 \%$ of our research sample. The average age of a child with Down syndrome in the families of our respondents was $8, S D=$ 6 . The children of the respondents in our research with Down syndrome were equally represented with respect to gender, i.e. $50 \%$ girls and $50 \%$ boys.

\section{Results}

In the first phase of data evaluation, we produced more detailed information on the number of respondents and their percentage as shown in Table 1.

Subsequently, we performed a content analysis of the data obtained from answers to the open question formulated in the questionnaire. It concerned support that parents needed but did not receive after learning of their child's diagnosis of Down syndrome. The percentage found in each category is described in Chart 1, which indicates that the greatest deficit was experienced by parents after the birth of a child with Down syndrome in terms of information, contacts or explanation. This 


\section{Table 1. Research sample characteristics}

\begin{tabular}{|c|c|}
\hline Variable & \\
\hline RESPONDENTS & Total sample $N=102$ \\
\hline Gender & \\
\hline Female & $86(84 \%)$ \\
\hline Male & $16(16 \%)$ \\
\hline Family status & \\
\hline Partner & 91 (89\%) \\
\hline Without partner & 11 (11\%) \\
\hline Qualification & \\
\hline Primary education & $2(2 \%)$ \\
\hline Secondary education & $49(48 \%)$ \\
\hline University Degree & $51(50 \%)$ \\
\hline Socio-economic status & \\
\hline Employed & 74 (73\%) \\
\hline Unemployed & $28(27 \%)$ \\
\hline Permanent residence & \\
\hline Town & $54(53 \%)$ \\
\hline Municipality & $48(47 \%)$ \\
\hline $\begin{array}{l}\text { CHILD OF A RESPONDENT WITH } \\
\text { DOWN SYNDROME }\end{array}$ & Total sample $N=102$ \\
\hline Gender & \\
\hline Female & $51(50 \%)$ \\
\hline Male & $51(50 \%)$ \\
\hline Siblings & \\
\hline No & $17(17 \%)$ \\
\hline Yes & $85(83 \%)$ \\
\hline Birth order & \\
\hline First-born & 25 (29\%) \\
\hline Middle child & $9(11 \%)$ \\
\hline The youngest child & $51(60 \%)$ \\
\hline Education & \\
\hline No & $35(34 \%)$ \\
\hline Kindergarten & 25 (25\%) \\
\hline Primary school & 42 (41\%) \\
\hline
\end{tabular}

group of unmet needs accounts for $30 \%$ of the total responses. An almost identical percentage of parents (29\%) reported that they lacked assistance from a specialist - psychologist - and this result is close to the need for encouragement from health professionals, which $10 \%$ of parents felt was unmet. A small percentage of respondents reported a financial and social deficit $-6 \%$; and $25 \%$ of parents said they did not lack any help, which may be caused by the fact that $88 \%$ of our respondents said they were receiving help from grandparents, while $48 \%$ said that grandparents were helping them with everything, and on average, $40 \%$ of respondents received help from grandparents.

HELP NOT PROVIDED

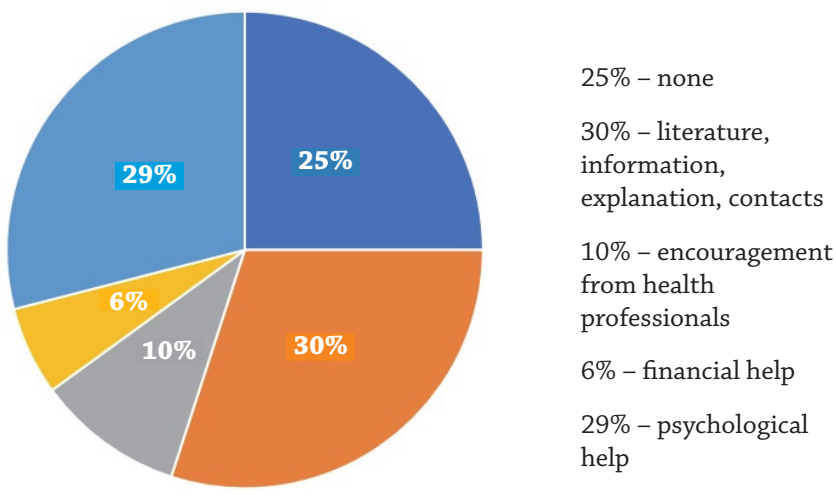

Chart 1. Percentage of unmet needs for support after the birth of a child with DS

The content analysis also showed that in the current situation, finance/compensation is the most needed element for families of children with Down syndrome $-20.8 \%$. However, educational needs $-19.8 \%$ or time $-19.8 \%$ - appear as almost equally desirable. Parents who claim to have everything $17.7 \%$, and parents who would like better family relationships $-13.5 \%$, form a large group too. The majority of the respondents were happy with their health status; only $8.3 \%$ of them indicated that their health status needed improvement at present (Chart 2).

CURRENT FAMILY NEEDS

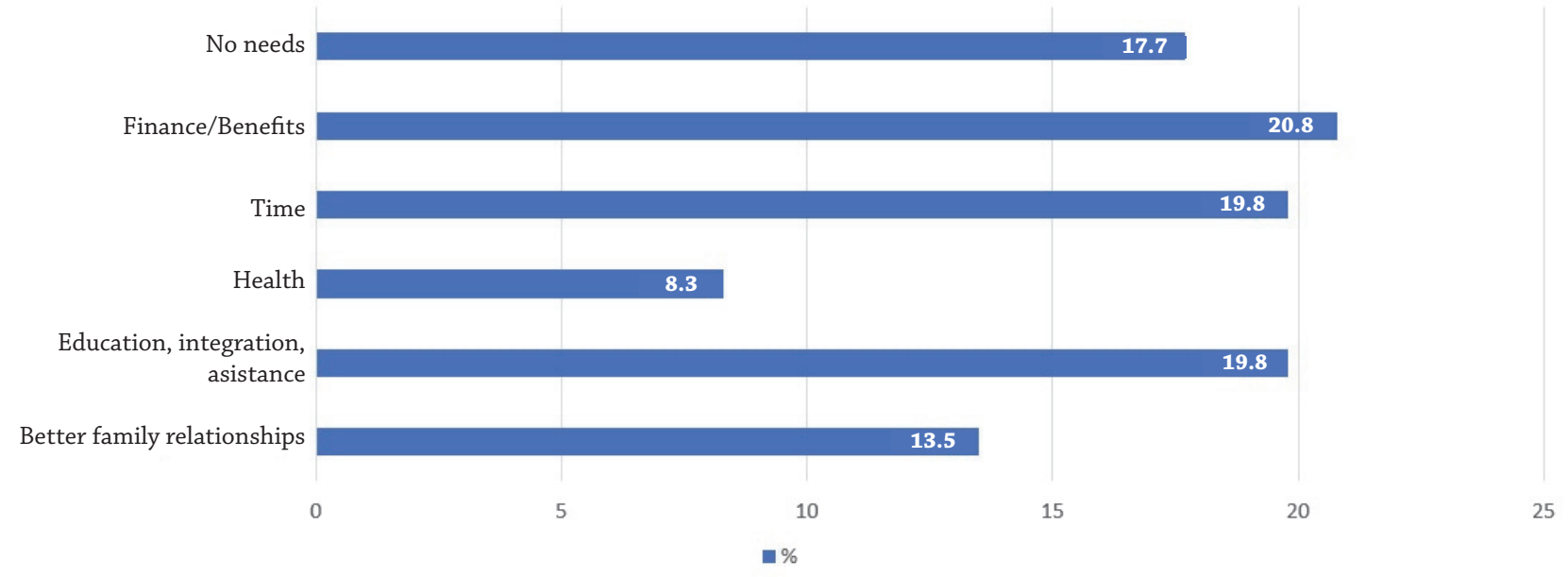

Chart 2. Answers to the question from the Family Needs Survey: What is currently most needed in your family? 
In the next part of the research we calculated the average score for the scales applied. The results of our research have shown that, on average, the respondents score highly in the Quality of Life Questionnaire $(M=80.25, S D=13.28)$. How- ever, a high score in the Family Needs Survey $(M=40.96, S D=$ 9.52) suggests that parents feel the need for assistance in the following areas of their life (Table 2).

Table 2. Descriptive statistical analysis of questionnaires

\begin{tabular}{|c|c|c|c|c|c|c|}
\hline$N=102$ & Minimum & Maximum & Modus & Median & $M$ & $S D$ \\
\hline FQOL RS & 20 & 100 & 79 & 81 & 80.25 & 13.82 \\
\hline Needs RS & 22 & 62 & 41 & 41 & 40.96 & 9.52 \\
\hline Child & 4 & 12 & 11 & 9 & 8.81 & 2.48 \\
\hline Support & 5 & 15 & 13 & 10 & 10.30 & 2.56 \\
\hline Explaining to others & 3 & 9 & 3 & 4 & 4.24 & 1.58 \\
\hline Community services & 3 & 9 & 5 & 5 & 5.35 & 1.88 \\
\hline Financial needs & 4 & 12 & 4 & 8 & 7.75 & 2.66 \\
\hline Family functioning & 3 & 9 & 3 & 4 & 4.51 & 1.71 \\
\hline
\end{tabular}

Notes: $N$ - number of respondents; RS - raw score; $M$ - arithmetic mean; $S D$ - standard deviation

The results of the correlation analysis showed that the higher the quality of life the respondents experience, as measured by the FQOL questionnaire, the less assistance they need in individual areas: Explaining To Others $\left(r_{\mathrm{s}}=-0.280 ; p>\right.$ $0.01)$, Community Services $\left(r_{\mathrm{s}}=-0.278 ; p>0.01\right)$ and Family Functioning $\left(r_{s}=-0.267 ; p>0.01\right)$. The most significant needs were identified in the dimensions of: Support $(M=10.30$; $S D=2: 56)$, Child $(M=8.81 ; S D=2.48)$ and Financial Needs $(M=7.75 ; S D=2.66)-$ Table 3 .

At the same time, we observed statistically significant differences in the quality of life of families receiving support from grandparents and those who do not receive this kind of support $(U=146 ; p<0.05)$. Respondents receiving assistance from grandparents showed a significantly higher quality of life $(M=81.71)$ than respondents without this kind of assistance $(M=71.54)$. The research also confirmed that the quality of life of respondents in our research is related to whether or not parents attend a self-help group. The result is shown in Table 3.

Table 3 shows that self-help groups account for a little more than $2 \%$ of the variance of FQOL, and whether a child with Down syndrome attends classes in an institution account for $1.6 \%$ of the variance of this variable.

With regards to the dimensions in the Needs Questionnaire, the statistical analysis confirmed several significant statistical differences and relationships between the individual dimensions of the questionnaire and the variables under review (Table 4).

Table 4 points to the important finding that there is a statistically significant difference in the level of support needed in individual groups of employed and unemployed parents,

\section{Table 3. Correlation between quality of life and membership} in self-help groups

\begin{tabular}{lccc} 
Variable & $\alpha ; p<0.05$ & Eta & \% variability \\
\hline Self-help groups & 52.78 & 0.150 & 2.25 \\
Attends classes in an institution & 91.94 & 0.126 & 1.59
\end{tabular}

Notes: $\%$ variability $=\mathrm{Eta}^{2}{ }^{*} 100 ; \alpha-$ Chi-quadrat; $p$ - statistical significance

specifically in the area of Financial needs, $U=767.5 ; p<0.05$. In terms of the need for financial assistance, we also found differences in the groups of respondents with different levels of qualification, $\alpha=8.03 ; p<0.05$. Further analysis of the research data confirmed the existence of a statistically significant relationship between the demographic variable qualification and the area of Financial needs $\left(r_{s}=-0.255 ; p<0.01\right)$. A negative correlation suggests hat the higher education the respondents achieved, the lower their need for financial assistance.

The research also confirmed the existence of a statistically significant difference in the overall score of need for assistance between families living together with grandparents and families living alone, $U=448 ; p<0.05$. We found a statistically significant difference in the level of need for help in the area of Explaining to others, $U=298.5$, between families living alone and those living together with grandparents; $p<0.01$, and Family functioning, $U=391 ; p<0.01$. At the same time, a statistically significant relationship between the variables of Shared household with grandparents and Explaining to others was also confirmed. This variable explains the $20 \%$ variance of the dimension $(\alpha=32.85 ; p<0.01)$.

Table 4. Correlation between Needs survey dimensions and independent variables

\begin{tabular}{|c|c|c|c|c|c|}
\hline Dimension & Variable & Statistical test & $p$ & Eta & $\%$ Variance \\
\hline \multirow{2}{*}{ Financial needs } & Employment & $\alpha=8.75$ & 0.364 & 0.201 & 4 \\
\hline & Qualification & $r_{s}=-0.255$ & 0.010 & - & - \\
\hline Child & Birth order & $r_{\mathrm{s}}=0.035$ & 0.726 & - & - \\
\hline Explaining to others & \multirow{2}{*}{$\begin{array}{l}\text { Joint household with } \\
\text { grandparents }\end{array}$} & $\alpha=32.85$ & 0.000 & 0.452 & 20.4 \\
\hline Family functioning & & $\alpha=11.59$ & 0.072 & 0.314 & 10 \\
\hline
\end{tabular}


Depending on the birth order of the child with Down syndrome, we found statistically significant differences in the need for assistance within the Child dimension between the individual groups of "the only child, firstborn, middle and the last children", $\alpha=9.24 ; p<0.05$.

We were also wondering whether these demographic variables were related to other dimensions in the Needs Questionnaire too. Statistical significance has been shown only within the variables Family functioning and qualification, $r_{s}=-0.255$; $p<0.05$. This finding suggests that the higher qualification the parents of children with Down syndrome achieved, the lower their need concerning functioning of the family system.

\section{Discussion}

The aim of this study was to identify the needs of parents of children with Down syndrome. We did not only focus on the needs perceived at present, but we were also interested in the needs of parents after the birth of their child with a disability - which they consider insufficiently met. We also examined the quality of their lives. In order to define the significance of the impact that a social situation such as the birth of a child with Down syndrome has on the lives of parents and the whole family, we have used two valid standardized worldwide scales: Family Needs Survey (FNS) and Family Quality of Life Scale (FQOL) with a focus on families of children with disabilities.

The results of this study showed that parents considered the need for information, explanation and contacts, and mostly the need for professional psychological assistance as some of their greatest needs - and at the same time these were the least met needs after the birth of a child with Down syndrome. The deficit in this area felt by parents of children with Down syndrome is also confirmed by Vágnerová et al. (2009) as well as in the results of further studies. A study by Nunes and Dupas (2011) confirmed our finding that the timing and the form of the provision of information to parents was inadequate. The information provided was pessimistic, incomplete, and failed to provide parents with the necessary explanations, leaving the family anxious. Thus the information given did not allow them to cope with the new situation, harmed the formation of an attachment with the child, and prevented families from overcoming the sadness of the situation (Gromošová, 2017; Nunes and Dupas, 2011). In their study, Huiracocha et al. (2017) report that the unequal status between doctors and parents may be at the core of insufficient and inappropriate information provided to parents (Peck and Conner, 2011). On the other hand, doctors also indicate that gicing the diagnosis of Down syndrome to parents is very stressful for them (Vehkakoski, 2007), which may be due to the fact that, according to the Pickering and Busse study (2010), doctors and healthcare professionals lack skills in sensitive communication and thus in announcing the diagnosis. All these facts affect the quality of communication with the child's family. This finding is very important considering that a sensitively givendiagnosis of Down syndrome can offer parents hope and facilitate its acceptance (Huiracocha et al., 2017).

As indicated by the above-mentioned studies, improper provision of primary information may result in severe stress on the parents' side. Several studies have confirmed that most parents who find out that their new-born child has Down syndrome will experience horror and shock. Regardless of how much they learn to cope with the situation in the coming years, the initial phase is extremely challenging for most of them. Almost everyone is experiencing confusion and anx- iety (Duchoslavová, 2007; Nunes and Dupas, 2011). Perhaps that is why the parents mentioned the need for professional psychological assistance as the second most important need when their child with Down syndrome was born. The parents' need for psychological assistance and the need for post-natal information refers to the lack of timely intervention, which has proven to improve parents' quality of life and helps them to reduce the stress arising from a new situation. Mohammed Nawi et al. (2013) and Bailey et al. (2004) confirmed in their studies that not only the early intervention itself, but also its timing is a very important factor affecting the quality of life of a family with a child who has Down syndrome. Parents who were provided with early intervention later, indicated lower quality of life than parents who received it in time.

These findings regarding the needs of parents of children with Down syndrome just after birth are consistent with the findings of the Needs Questionnaire analysis of current needs. The results showed that the most pronounced need perceived by parents was related to the area of Support, which contains statements about the need to communicate with a psychologist, social worker, teacher, therapist, but also other parents of children with the same type of disability. Another need is related to the dimension of Child, which concerns information about the disability or the upbringing of a child with Down syndrome. In addition to support and information, parents, nowadays, perceive the greatest need to be funding and compensation, the need to educate their children with Down syndrome, and the need for time. All identified needs are in line with the findings of Slaná et al. (2017) on the needs of families of children with disabilities in general. According to Read et al. (2006), the birth of a child with a disability or a chronic illness has a very negative impact on the financial situation of the family as a result of two major factors. Firstly, the family is confronted with the increased cost of childcare, including more frequent use of healthcare services, the need for special examinations (Hudecová et al., 2009), the use of multiple support services (Al-Dababneh et al., 2012), the use of compensatory and rehabilitation aids, or the reimbursement of medicines, treatment and rehabilitation stays, and secondly, there is a need for long-term continuous care, often requiring one parent to leave their job, thereby losing a significant part of their income (Slaná et al., 2017; Vágnerová et al., 2009). Due to the above-mentioned challenges in caring for a child with Down syndrome, parents and other family members end up having to invest a lot of their time into care. This may be the reason why lack of time was perceived so strongly by parents. A number of obligations arising from increased care for a child with Down syndrome can make parents unable to find time for themselves, and their needs and interests as part of emotional hygiene (Slaná et al., 2017). Hoogsteen and Woodgate (2010) point out that such repression of one's own needs can also lead to disruption of partnerships or family relationships. On the other hand, according to Slaný and Šramatá (2012), time that parents spend with their children is of the highest value. It helps them to create the sense of a secure and caring environment, which is very important for a child with Down syndrome. As already mentioned, one consequence of Down syndrome is the presence of mental disability, which can be mild, moderate, severe or profound. The impairment of intellectual abilities causes various complications in the child's daily life, the most pronounced being a learning disorder and dealing with difficult life situations - which to some extent also explains the above-mentioned need perceived by parents; the need to engage the child in the educational process (Kliewer, 1998; Slaná et al. 2017). 
Further results of our research showed that the quality of life of our respondents - and hence the parents of children with Down syndrome - was considerably high. The factor identified as the one which significantly increased the quality of life of parents in our research was the help and support of their community. According to our findings, the most important element in this area was assistance from grandparents, as well as membership in self-help groups or attending facilities or institutions - which is mentioned in other studies, too (Hauser-Cram et al., 2001; Strnadová, 2008). According to Sikorová and Polochová (2014), getting help from the closest social support network, seeking spiritual support, re-defining the stressful event, looking for resources in society through civic associations, self-help groups or social and health services are some of the strategies that help to cope with stress and the burden of caring for children with disabilities on the part of parents. Research has shown that the most widely used coping strategies of parents of children with chronic illness or disability in managing their stress is the ability to reframe the difficult life situation and gain social support (Hatzmann et al., 2009; Huiracocha et al., 2017; Luther et al., 2005). Sobotková (2004) also points out that in the case of a situation such as the birth of a child with a disability, the family should strive to mobilize and develop all its family forces and sources of support. The family thus becomes stronger and more resilient in dealing with specific problems (Sobotková, 2007). The results of our research confirm that our respondents mainly benefit from support of the grandparents, which can be described as complex help, as they provide them with psychological, social and financial support. According to Turnbull and Rueff (1996), a long-term and comprehensive family support system is essential for improving the quality of life of families with children with disabilities.

Help and support from grandparents was therefore an important factor affecting both the quality of life and the needs of parents. In terms of their emotional experience, our respondents did not differ significantly in variables such as age, sex, qualification, marital status, employment or sex and the age of the child, as we expected from former studies (Hauser-Cram et al., 2001; Sarimski, 2015). Rather, the rate of assistance from grandparents was an important factor. Respondents living in a three-generation family home together with the grandpar- ents showed a higher quality of life, a better functioning of the family, or a lower need to explain their child's disability to others than the rest of the respondents. In addition to support from grandparents, an important factor influencing the quality of life of our respondents included activities within selfhelp groups or institutions and facilities, which are considered by many authors a positive influence on family functioning, parents' adaptation to the situation and family characteristics (Hauser-Cram et al., 2001; Haveman, 2007; Sarimski, 2015).

The results of our research proved that informal as well as formal support from the environment and the timeliness of the intervention are very important factors for parents who have a child with Down syndrome in terms of improving their quality of life. As our research showed, the higher the quality of life of parents of children with Down syndrome, the less the need for help in the functioning of the family, explaining the child's disability to people in the neighbourhood, and the use of community services.

\section{Conclusions}

The results of our research imply two important facts. The key period for a family with a child with Down syndrome is the time when the diagnosis is announced to the family. At this point, they need complex help and support. It is important for parents to receive as much relevant information as possible about the disability, as well as the subsequent health, social and psychological support. Equally important for the quality of family life is the informal support provided by relatives of children with Down syndrome. The types of individual support vary according to the period of the child's life. As a rule, the sooner the support is provided, the higher the quality of family life.

\section{Conflict of interests}

The authors have no conflict of interests to declare.

\section{Acknowledgement}

This article was written with the support of APVV [Grant No APVV-14-0646].

\section{Výskum potrieb rodín s dietatom s Downovým syndrómom v kontexte Slovenska}

\section{Súhrn}

Ciel: Ciel'om výskumu bolo zistit', aké potreby majú rodičia dietatáa s Downovým syndrómom (DS) v súčasnosti, ktoré potreby neboli naplnené $\mathrm{v}$ čase diagnostikovania DS u dietatata a aký je vzt'ah medzi potrebami rodičov dietatata s DS a ich kvalitou života. Metódy: Pre naplnenie ciel'a sme využili dve validné štandardizované škály: Dotazník potrieb rodiny (FNS - Family Needs Survey) a Dotazník kvality života rodín so zdravotne postihnutým členom (FQOL - Family Quality of Life). Výskumnú vzorku tvorilo 102 rodičov detí s DS. Získané dáta sme spracovali s využitím obsahovej analýzy dát a štatistického spracovania dát prostredníctvom programu SPSS.

Výsledky: Zistili sme, že rodičia tesne po narodení diet́at́a s DS pocit́ovali najväčšie potreby v oblasti chýbajúcich informácií a psychologickej pomoci a vo vyššom veku dietatáa potrebu formálnej či neformálnej podpory, finančnej pomoci, zapojenia dietata s DS do vzdelávacieho procesu a potrebu času. Zároveň vel'mi silným faktorom pozitívne ovplyvňujúcim potreby rodičov detí s DS $(U=448 ; p<0.05)$ ako aj kvalitu ich života $(U=146 ; p<0.05)$ bola pomoc zo strany starých rodičov a svojpomocných skupín $(\alpha=52.78 ; p<0.05)$. Č́m sa u rodičov prejavovala vyššia kvalita života, tým viac klesala potreba pomoci v oblasti fungovania rodiny $\left(r_{\mathrm{s}}=-0.267 ; p>0.01\right)$, využívania komunitných služieb $\left(r_{\mathrm{s}}=-0.278 ; p>0.01\right)$ či vysvetl'ovania zdravotného postihnutia dietata okoliu $\left(r_{\mathrm{s}}=-0.280 ; p>0.01\right)$.

Záver: Pre uspokojovanie potrieb rodín s dietatom s DS je rovnako dôležitá formálna aj neformálna podpora. Druhy jednotlivej podpory variujú podl'a obdobia života diet́ata. Služby poskytované týmto rodinám majú byt' nielen komplexné, ale aj koordinované a kontinuálne.

Kl'účové slová: Downov syndróm; kvalita života; potreby; rodičia; zdravotné postihnutie 


\section{References}

1. Al-Dababneh K, Fayez M, Bataineh O (2012). Needs of parents caring for children with physical disabilities: a case study in Jordan. Int J Spec Educ 27(3): 120-133.

2. Alexander T, Walendzik J (2016). Raising a child with down syndrome: do preferred coping strategies explain differences in parental health? Psychology 7(1): 28-39. DOI: 10.4236/ psych.2016.71005.

3. Bailey DB, Simeonsson RJ (1988). Family Needs Survey. J Spec Educ 22(1): 117-127.

4. Bailey DB, Hebbeler K, Scarborough A, Spiker D, Mallik S (2004). Family outcomes at the end of early intervention: national early intervention longitudinal study. Menlo Park, CA: SRI International.

5. Duchoslavová L (2007). Down syndrome. Kontakt 9(2): 416-421. DOI: 10.32725/kont.2007.063.

6. Ekstein S, Glick B, Weill M, Kay B, Berger I (2011). Down Syndrome and Attention-Deficit/Hyperactivity Disorder (ADHD). J Child Neurol 26(10): 1290-1295. DOI: $10.1177 / 0883073811405201$.

7. Evans DW, Gray FL (2000). Compulsive-like behavior in individuals with Down syndrome: its relation to mental age level, adaptive and maladaptive behavior. Child Dev 71(2): 288-300. DOI: 10.1111/1467-8624.00144.

8. Feeley KM, Jones EA (2008). Strategies to address challenging behaviour in young children with Down syndrome. Down Syndrome Research and Practice 12(2): 153-163. DOI: 10.3104/ case-studies.2008.

9. Gallagher S, Phillips AC, Oliver C, Carroll D (2008). Predictors of psychological morbidity in parents of children with intellectual disabilities. J Pediatr Psychol 33(10): 1129-1136. DOI: $10.1093 /$ jpepsy/jsn040.

10. Gilmore L, Campbell J, Cuskelly M (2003). Developmental expectations, personality stereotypes, and attitudes towards inclusive education: community and teacher views of Down syndrome. Int J Disabil Dev Educ 50(1): 65-76. DOI: 10.1080/1034912032000053340.

11. Glenn SM, Cunningham CC (2000). Parents' reports of young people with Down syndrome talking loud to themselves. Ment Retard 38(6): 498-505. DOI: 10.1352/0047-6765(2000)038<0498:PROYPW> 2.0.CO;2.

12. Gromošová K (2017). Význam včasnej intervencie v starostlivosti o diet́a a rodinu. Skúsenosti z práce Centra včasnej intervencie Prešov. In: Zborník príspevkov z konferencie Včasná intervencia. Raná péče. Early intervention, 10.-11. 11. 2016 v Trnave. Trnava: Katedra sociálnej práce, Fakulta zdravotníctva a sociálnej práce Trnavskej univerzity v Trnave, pp. 42-50.

13. Hatzmann J, Maurice-Stam H, Heymans HSA, Grootenhuis MA (2009). A predictive model of Health Related Quality of life of parents of chronically ill children: the importance of caredependency of their child and their support system. Health Qual Life Outcomes 7: 72. DOI: 10.1186/1477-7525-7-72.

14. Hauser-Cram P, Warfield ME, Shonkoff JP, Krauss MW, Sayer A, Upshur CC (2001). Children with disabilities: a longitudinal study of child development and parent well-being. Monogr Soc Res Child Dev 66(3): i-viii, 1-114; discussion 115-126.

15. Haveman M (2007). Entwicklung und Früförderung von Kindern mit Down-Syndrom. Stuttgart: W. Kohlhammer Verlag $\mathrm{GmbH}$.

16. Hoffman L, Marquis J, Poston D, Summers JA, Turnbull A (2006). Family quality of life survey (FQOL): Psychometric evaluation of the beach center family quality of life scale. J Marriage Family 68(4): 1069-1083. DOI: 10.13072/ midss.327.

17. Hoogsteen L, Woodgate RL (2010). Can I play? A concept analysis of participation in children with disabilities. Phys Occup Ther Pediatr 30(4): 325-339. DOI: 10.3109/01942638.2010.481661.

18. Hudecová A, Brozmanová Gregorová A (2009). Sociálna práca s rodinou. Banská Bystrica: Univerzita Mateja Bela a OZ Pedagóg.
19. Huiracocha L, Almeida C, Huiracocha K, Arteaga J, Arteaga A, Blume S (2017). Parenting children with Down syndrome: Societal influences. J Child Health Care 21(4): 488-497. DOI: $10.1177 / 1367493517727131$.

20. Kliewer C (1998). Schooling children with Down syndrome: Toward an Understanding of Possibility. New York: Columbia University, Teachers College Press.

21. Kumin L (2003). Early communication skills for children with Down syndrome: a guide for parents and professionals. Bethesda, MD: Woodbine House.

22. Luther EH, Canham DL, Cureton VY (2005). Coping and social supports for parents of children with autism. J School Nurs 21(1): 40-47. DOI: 10.1177/10598405050210010901.

23. Matějček $Z$ (2001). Psychologie nemocných a zdravotně postižených dětí. Jinočany: H\&H.

24. Mohammed Nawi A, Ismail A, Abdullah S (2013). The impact on family among Down syndrome children with early intervention. Iran J Public Health 42(9): 996-1006.

25. Næss KA, Lyster SA, Hulme C, Melby-Lervåg M (2011). Language and verbal short-term memory skills in children with Down syndrome: A meta-analytic review. Res Dev Disabil 32(6): 2225-2234. DOI: 10.1016/j.ridd.2011.05.014.

26. Norizan A, Shamsuddin K (2010). Predictors of parenting stress among malaysian mothers of children with Down syndrome. J Intellect Disabil Res 54(11): 992-1003. DOI: 10.1111/j.13652788.2010.01324.x.

27. Nunes MD, Dupas G (2011). Independence of children with Down syndrome: the experiences of families. Rev Lat Am Enfermagem 19(4): 985-993. DOI: 10.1590/s010411692011000400018.

28. Peck BM, Conner S (2011). Talking with me or talking at me? The impact of status characteristics on doctor-patient interaction. Sociological Perspectives 54(4): 547-567. DOI: 10.1525/sop.2011.54.4.547.

29. Pickering D, Busse M (2010). Disabled children's services: how do we measure family-centred care? J Child Health Care 14(2): 200-207. DOI: $10.1177 / 1367493509360207$.

30. Pugnerová M, Konečný J (2012). Patopsychologie se zaměřením na psychologii handicapu. Olomouc: Univerzita Palackého v Olomouci, Pedagogická fakulta.

31. Read J, Clements L, Ruebain D (2006). Disabled children and the Law. London: Jessica Kingsley Publishers.

32. Roizen NJ, Magyar CI, Kuschner ES, Sulkes SB, Druschel C, van Wijngaarden E, et al. (2014). A community cross-sectional survey of medical problems in 440 children with Down syndrome in New York State. J Pediatr 164(4): 871-875. DOI: 10.1016/j.jpeds.2013.11.032.

33. Sarimski K (2015). Entwicklungsprofil, Verhaltensmerkmale und Familienerleben bei Kindern mit Down-Syndrom - Erste Ergebnisse der Heidelberger Down-Syndrom-Studie. Empirische Sonderpädagogik 7(1): 5-23.

34. Selikowitz M (2011). Downův syndrom: Definice a př́íčiny, Vývoj dítěte, Výchova a vzdělání, dospělost. 2nd ed. Praha: Portál.

35. Sikorová L, Polochová M (2014). Copingové strategie rodiny $\mathrm{s}$ chronicky nemocným dítětem. Coping strategies of family with a chronically ill child. Kontakt 16(1): 35-43. DOI: 10.1016/j. kontakt.2014.01.002.

36. Slaná M, Hromková M, Molnárová Letovancová K (2017). Včasná intervencia. Vývoj, súčasný stav a teoretické východiská. Trnava: Trnavská univerzita v Trnave.

37. Slaný J, Šramatá M (2012). Emoce a vážně nemocné dítě. Paliatívna medicína 5(3): 86-88.

38. Sobotková I (2004). Rodinná resilience. Československá psychologie 48(3): 233-246.

39. Sobotková I (2007). Psychologie rodiny. Praha: Portál.

40. Spangenberg JJ, Theron JC (2001). Stress and coping in parents of children with Down syndrome. Stud Psychol 43(1): $41-47$.

41. Strnadová I (2008). Rodiče dětí s Downovým syndromem: Vnímání postižení svého dítěte v kontextu vlastního života. Psychológia a patopsychológia diet́at́a 43(2): 118-128. 
42. Šustrová M, et al. (2004). Diagnóza: Downov syndróm. Bratislava: Spoločnost' Downovho syndrómu na Slovensku, UPKM.

43. Turnbull AP, Rueff M (1996). Family perspective on problem behavior. Mental retardation 34(5): 280-293.
44. Vágnerová M, Strnadová I, Krejčová L (2009). Náročné mateřství. Praha: Karolinum.

45. Vehkakoski TM (2007). Newborns with an impairment: discourses of hospital staff. Qual Health Res 17(3): 288-299. DOI: $10.1177 / 1049732306298348$. 